\title{
Hydrologic Data for Urban Studies in the Austin, Texas Metropolitan
}

Area, 1978

R.M. Slade, Jr., M.E. Dorsey, J.D. Gordon, and R.N. Mitchell

U.S. GEOLOGICAL SURVEY

Open-File Report 80-728

Prepared in cooperation with the City of Austin and the Texas Department of Water Resources 


\section{UNITED STATES DEPARTMENT OF THE INTERIOR}

CECIL D. ANDRUS, Secretary

GEOLOGICAL SURVEY

H. William Menard, Director

Reproduced by the Texas Department of Water Resources as part of the continuing program of cooperation in water-resources investigations between the Department and the U.S. Geological Survey. 


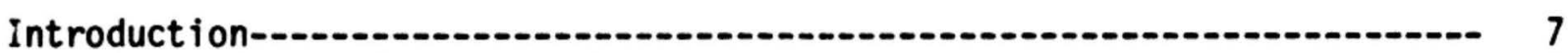

Location and description of the area-1

Data-collection methods-_- the 10

Precipitation data-10._. 10

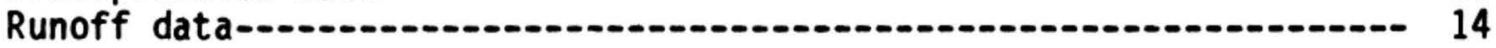

Water-quality data--_on 16

Ground-water data--and 16

Selected references-_._. 22

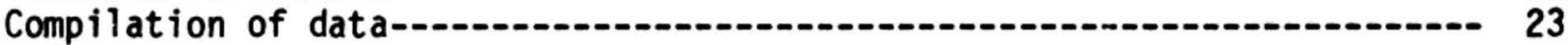

Colorado River:

Colorado River below Mansfield Dam, Austin, Tex...-..-...-...- 24

Bull Creek drainage basin-_. 25

Bull Creek at Loop 360 near Austin, Tex.

West Bull Creek at Loop 360 near Austin, Tex.

Bu? 1 Creek at Farm Road 2222 near Austin, Tex........... 32

Lake Austin at Austin, Tex-... 34

Bee Creek drainage basin-_-_. 36

Bee Creek at West Lake Drive near Austin, Tex....... 38

Barton Creek drainage basin-........ 39

Barton Creek at State Highway 71 near Dak Hill, Tex....................- 42

Storm of June 6-7, 1978-.-..- 45

Barton Creek at Loop 360, Austin, Tex,

Barton Springs at Austin, Tex......... 48

Barton Creek below Barton Springs at Austin, Tex......- 50

West Bouldin Creek drainage basin-..- 53

West Bouldin Creek at Riverside Drive, Austin, Tex.-.-. 55

Shoal Creek drainage basin-_. 56

Shoal Creek at Steck Avenue, Austin, Tex.

Storm of February 12, 1978-- 61

Storm of May 2-3, 1978---1 62

Storm of May 11, 1978--.-1.-- 63

Shoal Creek at Northwest Park, Austin, Tex.-.- 64

Storm of February 12, 1978

Storm of May 2-3, 1978-_-1 67

Storm of May 11, 1978-_...... 68

Shoal Creek at White Rock Drive, Austin, Tex..-..- 69

Storm of February 12, 1978--.- 70

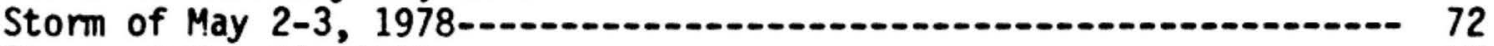

Storm of May 11, 1978-_-_.-.-1 73

Shoal Creek at 12th Street, Austin, Tex...... 74

Storm of May 2-3, 1978

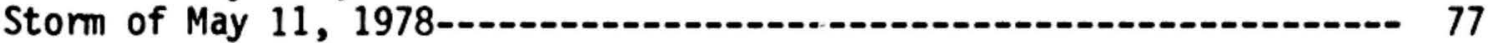


Compilation of data--Continued

Colorado River:--Continued

Waller Creek drainage basin--.-1..-

Waller Creek at 38th Street, Austin, Tex.

Storm of February 12, 1978-

Storm of May 2-3, 1978--

Storm of May 11, 1978

Waller Creek at 23rd Street, Austin, Tex.

Storm of February 12, 1978-

Storm of May 2-3, 1978-_.

Storm of May 11, 1978--

Town Lake at Austin, Tex.

Colorado River at Austin, Tex.

Boggy Creek drainage basin-

Boggy Creek at U.S. Highway 183 near Austin, Tex.

Walnut Creek drainage basin-......

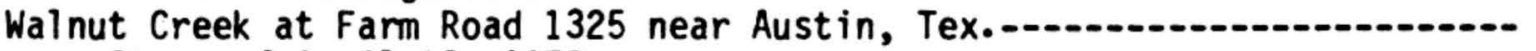

Storm of April 10, 1978

Wells Branch at Parmer Lane near Austin, Tex.

Walnut Creek at Dessau Road, Austin, Tex.

Storm of February 12, 1978-19.

Storm of April 10, 1978-

Storm of June 6-7, 1978--

Ferguson Branch at Springdale Road, Austin Tex.......

Little Walnut Creek at Interstate Highway 35,

Austin, Tex.

Little Walnut Creek at Manor Road, Austin, Tex........ 132

Storm of February 12, 1978- 133

Storm of May 2-3, 1978-_. 134

Storm of May 11, 1978-_-_._.-135

Walnut Creek at Webberville Road, Austin, Tex.......... 136

Storm of May 2-3, 1978-_. 140

Storm of May 11-12, 1978-_en

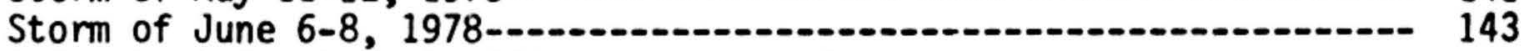

Walnut Creek at Southern Pacific Railroad Bridge,

Austin, Tex.

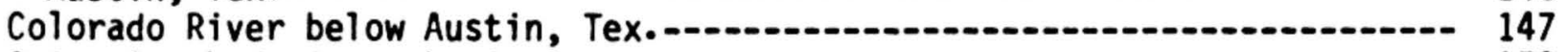

Onion Creek drainage basin-

Onion Creek near Driftwood, Tex.

Onion Creek at Buda, Tex.

Bear Creek below F.M. Road 1826 near Driftwood, Tex.......- 157

Little Bear Creek at F.M. Road 1626 near

Manchaca, Tex. 


\section{CONTENTS--Cont inued}

Compilation of data--Continued

Colorado River--Continued

Slaughter Creek drainage basin-- 160

Slaughter Creek at F.M. 1826 near Austin, Tex.

Slaughter Creek at F.M. 2304 near Aust in, Tex.

Boggy Creek (south) drainage basin-a 164

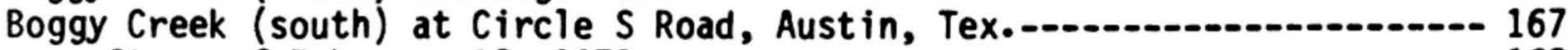

Storm of February 12, 1978-_. 168

Storm of May 2-3, 1978-_e 169

Williamson Creek drainage basin-.-.- 170

Williamson Creek at Oak Hill, Tex..-...-...- 173

Williamson Creek at Manchaca Road, Austin, Tex.............- 176

Storm of April 10, 1978-177

Storm of May 2-3, 1978-_. 178

Storm of June 6-7, 1978--..-179

Williamson Creek at Jimmy Clay Road, Austin, Tex...... 181

Storm of April 10, 1978-_. 185

Storm of May 2-3, 1978-_. 187

Storm of June 6-8, 1978-_-_. 188

Onion Creek at U.S. Highway 183, Austin, Tex. 190

Wilbarger Creek drainage basin-1..... 194

Wilbarger Creek near Pflugerville, Tex....... 195

Daily and monthly rainfall summary for gages west of meridian $97^{\circ} 45^{\prime}-1$.

Daily and monthly rainfall summary for gages east of meridian $97^{\circ} 45^{\prime}-$ 


\section{ILLUSTRATIONS}

Page

Figure 1. Map showing locations of surface-water hydrologicinstrument installations and surface-waterquality sampling sites in the Austin urban study area-cin 11

2. Map showing locations of water-quality datacollection sites on Town Lake-17

3. Map showing locations of ground-water datacollection sites in Travis County- 18

4. Map showing locations of ground-water datacollection sites in Hays County-a 19

5-15. Map showing locations of surface-water datacollection sites in the:

5. Bull Creek drainage basin- 26

6. Bee Creek drainage basin- 37

7. Barton Creek drainage basin-_ 40

8. West Bouldin Creek drainage basin- 54

9. Shoal Creek drainage basin- 57

10. Waller Creek drainage basin- 79

11. Boggy Creek drainage basin-_ 115

12. Wainut Creek drainage basin-_- 120

13. Slaughter Creek drainage basin

14. Boggy Creek (south) drainage basin-_. 165

15. Williamson Creek drainage basin-171 


\section{TABLES}

Page

Table 1. Weighted-mean precipitation factors for drainage basins above stations in the Austin metropoitian

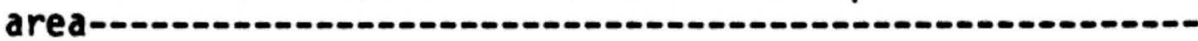

2. Rainfall and runoff data for selected continuous-record gaging stations in the Austin urban study area, 1978 water year--

3. Peak discharges associated with water-quality samples

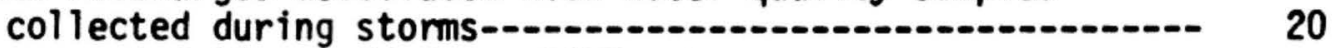

4-9. Storm rainfall-runoff data, 1978 water year,:

4. Barton Creek-- 41

5. Shoal Creek-1.- 58

6. Waller Creek -

7. Walnut Creek-1.-1

8. Boggy Creek (South)-_. 166

9. Williamson Creek

10. Records of wells, test holes, and springs in the Austin urban study area,

- Travis County-.--_-1 196

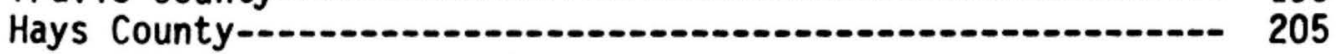

11. Water-quality data from wells and springs in the Austin urban study area, Travis County-_.-.-10 210 Hays County--.-16 
HYDROLOGIC DATA FOR URBAN STUDIES IN THE

AUSTIN, TEXAS, METROPOLITAN AREA

1978

By

R. M. Slade, Jr., M. E. Dorsey, J. D. Gordon, and R. N. Mitchell U.S. Geological Survey

\section{INTRODUCTION}

Hydrologic investigations of urban watersheds in Texas were begun by the U.S. Geological Survey in 1954. Studies are now in progress in Austin, Dallas, Dallas County, Fort Worth, Houston, and San Antonio.

The Geological Survey, in cooperation with the Texas Department of Water Resources, began hydrologic studies in the Aust in urban area in 1954. In cooperation with the city of Austin, the program was expanded in 1975 to include additional streamflow and rainfall gaging stations and the collection of waterquality data. In 1978, the program was expanded to include a ground-water resources study of the South Austin metropolitan area in the Balcones Fault Zone.

The objectives of the Austin urban-hydrology study are as follows:

1. To determine, on the basis of historical data and hydrologic analyses, the magnitude and frequency of flood peaks and flood volume.

2. To determine the effect of urban development on flood peaks and volume.

3. To determine the variations in water quality during different seasons in selected basins under various types of urban development.

4. To quantitatively appraise the ground-water resources along the Balcones Fault Zone, the effect of urbanization on the quality and quantity of recharge and discharge, and the extent of pollution in the Edwards aquifer. 
This report presents the hydrologic data collected in the Austin urban area for the 1978 water year (Oct. 1, 1977 to Sept. 30, 1978). To facilitate the publication and distribution of this report at the earliest feasible time, certain material has been included that does not conform to the formal publication standards of the U.S. Geological Survey.

The inch-pound units of measurements used in this report may be converted to metric units by using the following conversion factors:

\begin{tabular}{|c|c|c|c|c|}
\hline \multicolumn{2}{|l|}{ From } & \multirow{2}{*}{$\begin{array}{c}\text { Multiply } \\
\text { by }\end{array}$} & \multicolumn{2}{|l|}{ To obtain } \\
\hline Unit & $\begin{array}{l}\text { Abbrevia- } \\
\text { tion }\end{array}$ & & Unit & $\begin{array}{c}\text { Abbrevia- } \\
\text { tion } \\
\end{array}$ \\
\hline inch & -- & 25.4 & millimeter & $m m$ \\
\hline foot & -- & 0.3048 & meter & m \\
\hline mile & -- & 1.609 & kilometer & km \\
\hline square mile & $m i^{2}$ & 2.590 & square kilometer & $\mathrm{km}^{2}$ \\
\hline $\begin{array}{l}\text { cubic foot } \\
\text { per second }\end{array}$ & $\mathrm{ft}^{3} / \mathrm{s}$ & 0.02832 & cubic meter per second & $\mathrm{m}^{3} / \mathrm{s}$ \\
\hline foot per mile & $\mathrm{ft} / \mathrm{mi}$ & 0.189 & meter per kilometer & $\mathrm{m} / \mathrm{km}$ \\
\hline acre-foot & -- & 1233 & cubic meter & $m^{3}$ \\
\hline & & 0.001233 & cubic hectometer & $\mathrm{hm}^{3}$ \\
\hline
\end{tabular}

Additional explanations of terms related to streamflow, water quality, and other hydrologic data used in this report are defined in the U.S. Geological Survey annual report Water Resourses Data for Texas, TX-78-3, 1978. 


\section{LOCATION AND DESCRIPTION OF THE AREA}

The Austin study area is about 80 miles northeast of San Antonio and about 160 miles northwest of Houston. The study area extends from the Hill Country at the eastern edge of the Edwards Plateau across the Balcones Escarpment to the Blackland Prairie of Texas. The land surface decreases in altitude from about 1,100 feet above NGVD (National Geodetic Vertical Datum of 1929) in the northwest to about 420 feet above NGVD level in the southeast.

Slopes generally range from 2 to 15 percent; slopes greater than 5 percent occur along the eastern edge of the Edwards Plateau, average about 5 percent within the Balcones Fault Zone, and are less than 5 percent east of the escarpment and along the flood plains and alluvial terraces of the Colorado River and its tributaries.

Soils overlying the hard limestone in the western half of the study area are in general poorly developed thin calcareous clays, clay loams, and stony clays. Bedrock is locally exposed. Soils on the soft limestones and shales of the Balcones Fault Zone are generally dark brown calcareous clays, clay loams, or silty clay loams 6 inches or more thick. Soils on the shaly formation in the eastern part of the area are dark gray to olive calcareous clays and clay loams, 12 inches or more thick. Soils on the flood plains and terraces of the Colorado River and its tributaries are dark gray to red-brown, calcareous, nciicalcareous, sandy loams, silty clay loams, clay loams, and gravelly sands 12 inches or more thick.

Detailed descriptions of the soils in the Austin urban study area can be found in Soil Survey of Travis County, U.S. Dept. of Agriculture, 1974. Additional geologic information in the Austin urban study area can be found in publications by the University of Texas Bureau of Economic Geology.

The major streams in the study area are the Colorado River, Onion Creek, Barton Creek, Walnut Creek, Bull Creek, Boggy Creek, Shoal Creek, Williamson Creek, Slaughter Creek, and Waller Creek. Throughout the year, low flow for some of the smaller streams in the predominantly urban areas is partly sustained by return flow from commercial use; during the summer months, the low flow is partly sustained by drainage from municipal and private swimming pools and from residential use. 
The climate of the Austin urban area is characterized by short mild winters, long moderately hot summers, moderately high humidity, and prevailing southerly winds. Records of the National Weather Service show that the mean annual temperature (based on the period $1941-70$ ) is $70.6^{\circ} \mathrm{F}\left(21.5^{\circ} \mathrm{C}\right.$ ); the mean maximum temperature for July is $95^{\circ} \mathrm{F}\left(35.0^{\circ} \mathrm{C}\right)$; and the mean minimum temperature for January is $41^{\circ} \mathrm{F}\left(5.0^{\circ} \mathrm{C}\right)$. The average gruwing season is about 270 days.

The average rainfall (based on the period 194l-70) is 32.49 inches and is generally well distributed throughout the year; however, individual storms may cause flooding in any season. The major storms usually occur during the months of April-May and September-October.

\section{DATA-COLLECTION METHODS}

The drainage basins, locations of hydrologic-instrument installations, anu surface-water-quality sampling sites in the Austin urban study area are shown on figure 1. The locations of hydrologic instruments and datacollection sites in the individual drainage basins are shown on figires 5-15.

\section{Precipitation Data}

Precipitation data are based on 24 recording rain gages. The gages are distributed throughout the drainage basins to measure total precipitation and to define rainfall intensities.

Precipitation at indivudual gages and weighted precipitation in each basin is given in the section "Compilation of data." Weighted-mean precipitation factors are shown in table 1. Weighted-mean precipitation for a study area is determined by the Thiessen method described by Linsley, Kohler, and Paulhus (1949). For example, the weighted-mean precipitation for the drainage basin upstream from the stream-gaging station Bull Creek at Loop 360 is computed as follows: Multiply the recorded precipitation at rain-gage 1 -BUL by 0.57 and to that value, add the recorded precipitation at rain-gage 2-BUL multiplied by 0.43 .

Rainfall for the current water year was unevenly distributed over the area. Individual station totals ranged from 23.95 inches at gage $6-R$ in the Waller Creek basin to 32.31 inches at gage 1-WLN in the Walnut Creek basin. The mean water-year total of all the rain gages is 27.83 inches as compared with the 30-year average (1941-70) of 32.49 inches at the Austin Municipal Airport. Daily and monthily precipitation data at individual gages in the study area are given in the section "Compilation of data."

Few storms of wide distribution produced rainfall totals of over 2 inches during the year. The most significant runofi-producing storm of the year occurred on May 2-3; rainfall totals for this storm ranged from 0.64 to 2.25 inches. Widespread showers also fell on February 12 and May 11 . These storms produced rainfall totals ranging from 0.46 to 1.92 inches, and 0.03 to 1.88 inches respectively. 